\title{
THE MODALITIES AND ROLES OF PESANTREN TO FACE THE ISSUES OF TERRORISM IN THE REGION OF MALANG
}

\author{
Gonda Yumitro, Dyah Estu Kurniawati, \\ Saiman, Peggy Puspa Haffsari \\ Universitas Muhammadiyah Malang \\ Jl. Raya Tlogomas, No. 246, Malang, Indonesia, 65144 \\ e-mail: gonda@umm.ac.id,dyahestu@gmail.com, saimanmhdris@gmail.com,peggy.puspa@gmail.com
}

\begin{abstract}
This study analysed the modalities and roles of pesantren (Islamic Boarding Schools) to face the issues of terrorism in the region of Malang. Contrary to the notion which stated that pesantren are the headquarters of terrorist groups, this paper discusses the existence of pesantren in the region of Malang with a various ideological background as the strategic and prominent stakeholders to face the issues of terrorism. The methodology was descriptive, with the concept of modality for deradicalisation. The result found that pesantren have modalities in dealing with issues of terrorism, namely, the spiritual modalities, the curriculum modality, the kyai and santri relations modality, and the social modality. Moreover, it is indicated that the pesantren and issues of terrorism are not interrelated. Pesantren have created an education system as the internal and external roles that can overcome the spread of radical movement activities and the issues of terrorism.
\end{abstract}

\begin{abstract}
Abstrak: Modalitas dan Peran Pesantren dalam Mengahadapi Isu Terorisme di Wilayah Malang. Studi ini menganalisa modalitas dan peran pesantren dalam menghadapi isu terorisme di wilayah Malang. Berbeda dengan pemikiran yang menyatakan bahwa pesantren merupakan pusat pengembangan bagi kelompok teroris, paper ini mendiskusikan keberadaan pesantren di Malang dengan latar belakang ideologi yang berbeda sebagai stakeholder yang strategis dan penting untuk menangani isu terorisme. Metodologi yang digunakan adalah diskriptif dengan konsep modalitas deradikalisasi. Adapun hasil yang ditemukan mengindikasikan bahwa pesantren mempunyai beberapa modalitas dalam menangani isu terorisme seperti modalitas spiritual, kurikulum, relasi kiai dan santri, serta modalitas social. Lebih lanjut, terdapat indikasi bahwa pesantren dan isu terorisme tidak terkait satu dengan lainnya. Pesantren sudah membangun sistem pendidikan sebagai bentuk peran internal dan eksternalnya untuk menyelesaikan penyebaran aktivitas gerakan radikal dan isu terorisme.
\end{abstract}

Keywords: pesantren, terrorism, Malang, modality, deradicalisation 


\section{Introduction}

In 2016 the Indonesian National Counter-Terrorism Agency (BNPT) stated that the 12 Terrorism Red Zone Regions in Indonesia included Central Java, Aceh, Jakarta, Banten, West Java, East Kalimantan, North Kalimantan, South Sulawesi, Central Sulawesi, NTB, Bali and East Java. ${ }^{1}$ The development of terrorism issues was due to the spread of hiding areas of radical groups throughout Indonesia. Related to the location of the study, the region of Malang is one of the areas that should be worried about being prone to terrorism. Some previous studies stated that Malang is a strategic location for perpetrators of the Thamrin bombing, Siyono case, and the spread of ISIS influence. ${ }^{2}$

Also, several studies in Malang showed data on the indications of the linkages between the Malang region and radical teachings. ${ }^{3}$ With the position of Malang, which is known as a city of education and city of tourism, many people come to this city with various destinations, both learning and tourism. In a terrorist perspective, these conditions can be used as attractive modalities to develop networks and recruit potential cadres.

Some data even shows that some areas in Malang are insecure. In the area of Dau, for example, Al Mustaqbal's magazine circulated as an ISIS group media, in which there were pictures of ISIS leaders and efforts to support jihad in Syria. ${ }^{4}$ Moreover, since many alumni of pesantren pursue their study in this region, some feel concerned about the regional security of Malang because some of these pesantren alumni were indicated as terrorists. ${ }^{5}$

Malang Raya is considered to have track records related to the issues of terrorism. In 2005 , in the city of Batu, the intellectual actor of Bali bombings, DrAzahari was caught. Moreover, Hendrawan, who was a member of Noordin M Top network, was arrested in 2009 when he was hiding in Batu. By the early January 2014, a bombing blasted at an ATM located in Karangploso, Malang Regency. In March 2015, six members of ISIS were arrested in Malang. ${ }^{6}$

${ }^{1}$ Bramantyo, "12 Daerah di Indonesia Masuk Zona Merah Terorisme, Termasuk Jawa Tengah," in https://news.okezone.com/, September 11, 2018.

${ }^{2}$ Gonda Yumitro, "Kebijakan Pemerintah Indonesia dalam Global War Against Terrorism," Prosiding Vennas 7 AIHII di Universitas Hasanuddin, Makassar, dengan Tema Benua Maritim Indonesia Dalam Perspektif Hubungan Internasional, November 23, 2016, p. 77; Ja'far, Ja'far. "Respons Al Jam'iyatul Washliyah Terhadap Terorisme," in Akademika: Jurnal Pemikiran Islam, Vol. 22, No. 1, 2017.

${ }^{3}$ Didi Syafirdi, "5 Masjid Disinyalir Jadi Tempat Penyebaran Paham ISIS di Malang," in https://www.merdeka.com/peristiwa/5-masjid-disinyalir-jadi-tempat-penyebaran-paham-isisdi-malang.html., Agustus 2014.

"Yatimul Ainun, "Majalah ISIS Beredar di Malang," in https://regional.kompas.com, Agustus 2014.

5Imam Zamroni, "Islam, Pesantren dan Terorisme," in Jurnal Pendidikan Agama Islam Vol. 2, No. 2, 2005, p. 188.

${ }^{6}$ Gonda Yumitro, "Kebijakan Pemerintah Indonesia dalam Global War Against Terrorism," in Prosiding Vennas 7 AIHII Di Universitas Hasanuddin, Makassar, Dengan Tema Benua Maritim Indonesia Dalam Perspektif Hubungan Internasional, November 23, 2016, p. 78. 
Responding to the threat of terrorism in East Java (including the region of Malang), the government has issued a Governor Regulation Number 51 of 2014 concerning Prohibition of ISIS. ${ }^{7}$ Referring back to the fact that Malang is both the city of education and a tourism city, the threat of radical ideologies has more potential to develop. With the coming of people from various regions in Indonesia, there is a concern that this terrorism movement can spread to all regions in Indonesia. Moreover, several mosques in Malang were indicated to teach the fundamentalism having a partial understanding of Islam. ${ }^{8}$ Furthermore, the Abu Jandal network or often known as Salim Mubarak Attamimi still exist, and his family lives in Malang. ${ }^{9}$ Regarding the pesantren which are considered as the cadre institution of Muslim scholars, there is a view said that terrorism is developed in some of the pesantren, Al Mukmin Ngruki in Surakarta, Azzaitun in Indramay, and Al Islam in Lamongan. ${ }^{10}$ Textual spirit in understanding Islam triggered this view making the students, and the people cannot understand the context of Islam. In the end, some alumni became the opposites of the West and could not keep up with the times. ${ }^{11}$ This view was developed and disseminated by various media. Based on the post-modernism perspective, public opinion has substantial power to influence people. With negative images of pesantren published by the media, many people believe in the issue. The fact is that some media publish their notion on a particular issue without validating the truth assuring that the published news is credible and have accountable references. ${ }^{12}$

Therefore, the notion of the close relation of terrorism issue and pesantren needs to be reviewed given the actual condition where pesantren have close ties to the history and the development of Indonesia as a country and nation. Indonesian history starting from the era of independence until now cannot be separated from Islam and the pesantren. Moreover, many programs and services have been performed by pesantren for Indonesia. When the issues of terrorism occurred, various pesantren actively participated to de-radicalise Islamic understanding among the society which may not be optimally socialised by various media.

Furthermore, the logic of this issue is that had pesantren provided a dangerous model of education; the threat of terrorism in Indonesia should have emerged since decades ago.

${ }^{7}$ Adibah Sayyidati, "Jawa Pos's News Reporting About Islamic State of Iraq and Syria (ISIS) in East Java on Peace Journalism Perspective (Potret Jawa Pos Tentang Islamic State of Iraq and Syria (ISIS) di Jawa Timur Dalam Perspektif Jurnalisme Perdamaian)," in Jurnal Pekommas Vol. 3, No. 1, April 2018.

8Imam Zamroni, "Islam, Pesantren dan Terorisme," p. 178.

${ }^{9}$ Najamuddin Khairur Rijal, "Local Governance Dalam Merespons Isu dan Ancaman ISIS: Kasus di Kota Malang," in Jurnal Social Politik Vol. 2, no. 1, 2017, p. 85-102.

${ }^{10}$ Zamroni, "Islam, Pesantren dan Terorisme," p. 179.

${ }^{11}$ Jemma Parsons, "Peran Pesantren dan Cita-Cita Santri Putri: Sebuah Pembandingan Diantara Dua Pondok Pesantren di Jawa," in https://1073zb3xfs20yv98x228do7r-wpengine.netdnassl.com/wp-content/uploads/2015/03/PARSONS-Jemma.pdf.

${ }^{12}$ Ken Andari, Dadang Rahmat Hidayat, and Efi Fadilah, "Konstruksi Majalah Gatra Tentang Radikalisme di Pesantren," in Students E-Journal, Vol. 1, No. 1, 2012, p. 18. 
The evidence showed that the development of this education model which has begun a long time ago before Indonesian independence with a thousand numbers of institutions does not indicate to bring the threat within the society. Moreover, Indonesia's independence and development were in line with the growth of Islamic education known as pesantren this country. ${ }^{13}$ Based on the description above, this study will elaborate on the question of how are the roles of pesantren to face the issues of terrorism in the region of Malang?. Before that, the writers will discuss several modalities owned by pesantren to meet the issues of terrorism with the concept of pesantren modality for deradicalisation. This study is different from some other studies which mostly see the positive correlation of terrorism issues and pesantren.

\section{The Concept of Modality for Deradicalisation in Pesantren}

Pesantren is defined as an educational system that demands the santri to stay in dormitories studying Islam and independent life. Usually, pesantren are established to prepare the cadre of Islamic scholars (clerics). ${ }^{14}$ Therefore, the dormitory system without Islamic tradition cannot be referred to a pesantren. The same condition applies to Islamic studies without staying in the dormitory, which is also not referred to as pesantren. In pesantren, the students have to follow full activities for 24 hours a day. ${ }^{15}$

The mission of pesantren is to provide integrative education for the santri to prepare their future life after joining the society. Therefore, the interaction of kyai and santri in pesantren is very close to the point that the kyai become the real model of santri to define their future identity. In here, the role of kyai is not only to transfer the knowledge but more importantly, is to give an example and to educate the santri to live as the ideal characteristic of Muslims. The modality of pesantren is the capacity owned by the institution to face various issues, such as terrorism. Regarding the issues of terrorism, the pesantren have internal modality which consists of spirituality, tolerance and multiculturalism curriculum, the unique relations between kyai and santri, and social modality. The problem is that many do not realise their modality. Therefore, mapping and awareness of various parties involved in facing the issues of terrorism are essential. Their roles in implementing the deradicalisation process will be possible to be conducted through understanding the concept of pesantren and the activities that have been carried out.

\footnotetext{
${ }^{13} \mathrm{Amir}$ Mu'allim, "Isu Terorisme dan Stigmatisasi Terhadap Pondok Pesantren: Meluruskan Kesalahpahaman terhadap Pondok Pesantren," in Millah: Jurnal Studi Agama, Vol. 6, no. 1, 2006. p. 47-60.

${ }^{14}$ Gamal Abdul Nasir Zakaria, "Pondok Pesantren: Changes and Its Future," in Journal of Islamic and Arabic Education Vol. 2, No. 2, 2010, p. 45-52.

${ }^{15}$ Pam Nilan, "The 'Spirit of Education'in Indonesian Pesantren," in British Journal of Sociology of Education Vol. 30, No. 2, 2009, p. 219-232.
} 
It is essential to be noted that the spirit of deradicalisation had begun a long time ago since the 17th century. However, this term has started being used often after the attack on the WTC on September 11,2001. Responding to that attack, during the GW Bush administration, USA declared a global war against terrorism which is often referred to as the global war on terrorism (GWOT) ${ }^{16}$ In its development, the issues of terrorism were increasingly widespread and growing. Some regions are considered as the front-runners in the development of terrorism issues, such as Afghanistan, Iraq, Syria, and Southeast Asia.

One of the fundamental problems regarding the issues of terrorism is that the definition of terrorism as the target of deradicalisation which has not been fully agreed. There were indications that terrorism is only the acts of violence committed by Muslim groups. Whereas, if the similar activities were carried out by other than Islam it would not be called as an act of terrorism, even though the violence had the motive to influence the public and government policies in various issues, despite it is only called as criminality. ${ }^{17}$

Since the issues have also been influenced by political interest, the definition of terrorism is often not objective. Theoretically, everybody can do acts of terrorism, including the state, if it raises an intimidating attitude towards its people. The violence action of the state is commonly called as state terrorism. ${ }^{18}$ The terrorist terminology should also be given to any extreme actions such as separatism, social revolution, and religious fundamentalism if it raises violence and terror within the society due to their actions. ${ }^{19}$

Currently, terrorism has become a global issue since the effects of its attack are very dangerous. Under the American leadership, the issue of deradicalisation is proliferating because GW Bush loudly divides the world into black and white, 'either you are with us, or you are with the terrorists. ${ }^{20}$ Some notions indicated that ' $u s^{\prime}$ is the same as the United State (of America), a picture of how strong and arrogant America is in the war against terrorism.

On the other hand, one of the essential factors of the emergence of terrorism was the policy of the American government which discriminated and exploited various parts of the Islamic world, where America also had close relations with some movements which in their further development emerged as the terrorist groups, such as the Taliban and ISIS. Under the support of America, these various groups eventually developed into a modern

${ }^{16}$ Douglas J. Feith, War and Decision: Inside the Pentagon at the Dawn of the War on Terrorism (New York: Harper Collins Publishers, 2008).

${ }^{17}$ Gregory Rose and Diana Nestorovska, "Towards an ASEAN Counter-Terrorism Treaty," in SYBIL 9, 2005, p. 157.

${ }^{18}$ Tore Bjorgo, Root Causes of Terrorism: Myths, Reality and Ways Forward (Routledge, 2004), p. 208.

${ }^{19}$ Omar A. Lizardo and Albert J. Bergesen, "Types of Terrorism by World System Location," in Humboldt Journal of Social Relations, 2003, 162-192.

${ }^{20}$ Gearoid Tuathail, “Just out Looking for a Fight': American Affect and the Invasion of Iraq," in Antipode Vol. 35, No. 5, 2003, p. 856-870. 
movement using various internet facilities establishing the cyber terrorism movement. ${ }^{21}$ For obtaining their interests, terrorist groups also developed their funding systems by selling illegal drugs and hacking. ${ }^{22}$

Unfortunately, the solution taken to face the issues of terrorism has not reached its point. Due to political interests and aggressive approaches domination in the deradicalisation framework, some policies even supported the development of terrorist groups instead. Terrorism issues should not be understood only in term of action and behaviour, but also in ways of thinking and mentality. Promoting tolerance and reasonable point of view should be spread to build mutual understanding among the people to minimise the potential of terrorism and political violence development. ${ }^{23}$ For such purpose, pesantren have the modality and have already performed some roles to participate in the war against terrorism.

\section{The Modalities of Pesantren in Facing Terrorism Issues}

In facing issues of terrorism, especially in the area of Malang, there are some potential modalities of pesantren which should be managed well. Those modalities are related to spirituality, curriculum, internal relations, and social modalities. The explanation can be understood as the following discussion.

\section{Spiritual Modality in Facing the Terrorism Issues}

Spirituality is essential in life since it contributes to the maturity of the wisdom of a person. Moreover, the existence of spirituality is in the mind and heart. Therefore, it becomes the highest level of personal development influencing the attitude of a person's social life since the existence of this modality is something transcendental related to God for the guidance of the life on the earth. ${ }^{24}$ However, most of the Americans did not define the spirituality connected to the issue of religion only. For those people, religion is related to the system of practices and beliefs, and only one of the expression of spirituality. Therefore, understanding of spirituality in term of religion only is too narrow, since it is about the way of understanding life. ${ }^{25}$

\footnotetext{
${ }^{21}$ James Andrew Lewis, Assessing the Risks of Cyber Terrorism, Cyber War and Other Cyber Threats (Center for Strategic \& International Studies Washington, DC, 2002), p. 8.

${ }^{22}$ Anthony L. Smith, "The Politics of Negotiating the Terrorist Problem in Indonesia," in Studies in Conflict \& Terrorism Vol. 28, No. 1, 2005, p. 33-44.

${ }^{23}$ Donatella Della Porta and Gary LaFree, "Guest Editorial: Processes of Radicalization and de-Radicalization," in International Journal of Conflict and Violence (IJCV) Vol. 6, No. 1, 2012, p. 4-10.

${ }^{24}$ Frances Vaughan, "What Is Spiritual Intelligence?," in Journal of Humanistic Psychology Vol. 42, No. 2, April 2002. p. 16-33, in https://doi.org/10.1177/0022167802422003.

${ }^{25}$ Jane Dyson and all, "The Meaning of Spirituality: A Literature Review," in Journal of Advanced Nursing, 1997, p. 6.
} 
In pesantren, most of the activities concerned with the development of spirituality. In Islam, religion as a whole becomes the way to understand the life since Islam has a mission to teach Muslims with the principles of taqwa, siddiq, amanah, tabligh, fathanah, faith, morality, visionary, discipline, and empathy. ${ }^{26}$ When Muslims have some of these characteristics, they can be claimed as spiritualist people. However, since having those label in life is not easy, the whole life of Muslims become the process of making their self being firm to those characters. All activities optimally are the process to follow the guidance of God.

All the expression of transcendental relation to God has social impacts in life. Therefore, all religious activities can be realised as spiritual activities. Usually, in the afternoon, the students join the preaching given by the kyai as well as in the morning they perform morning prayer and recite the Qur'an. Keeping prayers together in the mosque and fasting are also the routine activities followed by santri. All these transcendental activities influence social relations within the society where the Muslims have to perform peace and right attitude wherever they are. For instance, Islam teaches how to respect and appreciate others. In Islam, tolerance is very substantial, and it teaches followers to be far away from violence and from killing others. ${ }^{27}$

By joining routine preachings, the santri are expected to understand the Islamic way of life comprehensively. They will understand how the Islamic perspective in building relations with God, angels, and social life. Therefore, those joining the preaching understand how to interact with parents, neighbour, friends, Muslims, non-muslims, and all people. Furthermore, the more santri recite and understand Qur'an, the more they know how Islam has guided their attitude and behaviour in life.

Regarding the activities of prayers and fasting, Islam also teaches Muslims how to respond to the development of their society. All activities and statement in prayer started by saying Allahuakbar (Allah is the greatest) in the prayer, until salam (by saying peace be upon you) are the principle to create peaceful life within the society. Saying Allah is the greatest indicated that Muslims realise that they are small in front of Allah so that they will not be arrogant. Also, by saying, peace be upon you at the end of prayer depicted that Muslim should never disturb the others, for example, by being a part of the terrorist movement.

By the development and the concern of pesantren toward the spirituality, it is clear that the transcendental relations developed in the institution give positive effect for the santri and the people living within pesantren with tolerance values. Therefore, spirituality can be a prominent modality for facing terrorism.

${ }^{26}$ Hanifiyah Yuliatul Hijriah, "Spiritualitas Islam dalam Kewirausahaan," in Tsaqafah, Vol. 12, No. 1, 2016, p. 187-208.

${ }^{27}$ Chaiwat Satha-Anand, "The Nonviolent Crescent," in Nonkilling Spiritual Traditions, First Edition, Nonkilling Studies (Center for Global Nonkilling, 2015), p. 65. 


\section{Curriculum Modality: Tolerance and Multiculturalism}

There are some notions said that the curriculum in pesantren which cannot adapt and accept plurality values should be reviewed. In their point of views, the textual understanding of Islam in most pesantren in Indonesia has the potential to be prominent sources of terrorism ideologies spreading. ${ }^{28}$ Therefore, whatever the efforts to understand Islam mostly in term of context got the supports. Even, the image of Qur'an and hadith as the primary resources of Islam became harmful, for instance by saying that these two law resources of Islam support and legalise radical movements as the embryo of terrorist groups.

However, this view is dangerous and can be contra-productive toward the deradicalisation project since Islam itself is a peaceful religion. ${ }^{29}$ The critics toward pesantren curriculum can invite the radical groups to do some terror acts. Mutual understanding and trust among the elites and pesantren are the primary vital point to solve the issues of terrorism where governments need to understand the values and characteristics of the education in Pesantren.

The education system in pesantren is different from the education system in regular schools. In pesantren, besides studying general knowledge material given to students in public school, the santri also study the Qur'an, Hadith, Aqidah-Akhlaq, Muhadlara, and Arabic language. Therefore, the allocation of time for studying in pesantren is more than in the public education system. Moreover, the dormitory model also strongly supports the full activities of santri within this education system. The daily activities of the santri are divided into two types, namely academic and religious understanding. Both of them are under the supervision of the teachers, coaches and kyai.

The substance of the curriculum in pesantren does not only focus on improving the quality of santri towards the practice of worshipping. However, the curriculum is also designed to provide students with the understanding and practices of tolerance and multiculturalism. Through the subjects of Qur'an, Hadiths, Tarbiyah, Mahfudzot, Islamic history, Indonesian history, and the state administration, the students are taught to understand and implement values of tolerance and multiculturalism in their daily life.

Such condition is synergic with the framework of tolerance and multiculturalism as stated in Surah al-Kâfirûn verses 1-6 which are translated: O unbelievers. I will not worship what you worship. Also, you are not a worshiper of the Lord I worship. Moreover, I have never

${ }^{28}$ Mukhibat Mukhibat, "Deradikalisasi dan Integrasi Nilai-Nilai Pluralitas dalam Kurikulum Pesantren Salagi Haraki di Indonesia," in Al-Tahrir: journal of Islamic Thought Vol. 14, No. 1, 2014, p. 181-204.

${ }^{29}$ Gonda Yumitro, "Terrorism, Islam and International Politics," in Jurnal Studi Hubungan Internasional Vol. 2, No. 2, 2012, p. 168. See also Mhd. Syahnan, Contemporay Islamic Legal Discourse: A Study of Sayyid Quthb's Fi Zhilal al-Qur'an (Medan: IAIN Press, 2010); Mhd. Syahnan, "Islam as a System: A Critical Analysis of Sayyid Quthb's Principle Thought," in Analitica Islamica, Vol. 4, No. 1, May 2002, p. 45-57. 
been a devotee of what you worship, and you have never (also) become a worshiper of the Lord whom I worship. For you, your belief, and for me, my religion. The principles explained in this surah is fundamental and very prominent for the implementation of true tolerance with universal values. When Muslims respect other faiths by saying that they do not worship what the others worship, this also applies to the followers of other religions.

Therefore, one Islamic cleric in Indonesia Islamic Scholar Assembly said that the possibility of terrorism ideologies spreading through education is limited. Even pesantren can be labelled as the enemy of all radical actions. ${ }^{30}$ Moreover, Islamic scholars have the system to control the curriculum and education process among pesantren in Indonesia. In case there is something different, they have a forum to discuss and find the solution to the issue which is faced.

Based on the above explanation, it is clear that the development of religious or spirituality in the pesantren can be applied through the curriculum. Pesantren in various places also develop peace education in their respective institutions to portray Islam as a safe and peaceful religion. ${ }^{31}$ They also carried out various programs, including the preparation and development of anti-terrorism and education based on an inclusive multicultural curriculum basis. ${ }^{32}$

\section{Modalities of Kyai and Santri Relationship}

The relationship between kyai and santri in the pesantren is very close. The figure of kyai is a teacher with a positive and rightful image in the mind of the santri. Therefore, whatever the statements issued by the kyai tend to be followed by the santri. For them, kyai is considered as a good and wise person. The position of kyai is also the front guard of the morality protection within the society. When they are faced with any problems, santri and the people often consult to kyai in finding the best way to solve their problems.

With this kind of relationship, the pesantren have a strategic position to face the issues of terrorism. The most crucial point is the understanding of kyai towards Islam. If there is no error framework, kyai will easily be able to influence the santri and society to refresh their understanding of Islam with the spirit of peace. Even if there are santri who have a radical understanding of Islam, kyai has the power to purify their understanding.

${ }^{30}$ Rustam Ibrahim, "Pesantren dan Pendidikan Kebangsaan: Studi Tentang Buku Al-Difấ 'Ani al-Wathân min Ahammi al-Wâjibât 'ala Kulli Wâhidin Minnâ Karya Kiai Muhammad Said," in MIQOT: Jurnal Ilmu-ilmu Keislaman, Vol. 42, No. 1 , 2018, p. 148-170.

${ }^{31}$ Eneng Muslihah, "Pesantren dan Pengembangan Pendidikan Perdamaian Studi Kasus di Pesantren An-Nidzomiyyah Labuan Pandeglang Banten," in Analisis: Jurnal Studi Keislaman Vol. 14, No. 2, 2014, p. 311-340.

${ }^{32}$ Rohmat Suprapto, "Deradikalisasi Agama Melalui Pendidikan Multikultural-Inklusiv (Studi Pada Pesantren Imam Syuhodo Sukoharjo)," in Profetika: Jurnal Studi Islam, Vol. 15, No. 02, 2016, p. 246-260. 
Regarding some images saying that pesantren is closely connected with terrorism issues, the national history of Indonesia depicts that since the era of Indonesian independence, pesantren cannot be separated with the existence and the development of this country. In the era of independence, the kyai aroused the spirit of Muslims and santri to fight against invaders. Even in its development, Indonesia is also inseparable from the contribution of Muslims. Therefore, pesantren is one of the guards of the integrity of Indonesia, including from the threat of terrorism. ${ }^{33}$

\section{Social Modality}

The existence of kyaigives him some prominent roles within the society at the same time, as the religious leader, the owner and the founder of pesantren, the protector of Islamic culture, and the primary preacher for an Islamic understanding of people in the pesantren and society. Because of such roles, he gets support from the people, despite people trust on his morality and faith quality. ${ }^{34}$ It can be seen that the relations modality of kyai is not only internally within the pesantren, but also he has crucial roles within the society, especially with those graduated from pesantren or live nearby the pesantren.

Moreover, history has proved that the strategic position of pesantren is not only within the institutions. For most people in Indonesia, the tradition of pesantren indicated that the people staying within are good, wise and have a good understanding of Islam, particularly the position of kyai. Moreover, pesantren also often conducted some activities together with the society staying nearby their location. Whenever the people living around it facing problems related to the issue of religion, they regularly consult about the way to find the solution with the kyai.

With this evidence, pesantren become the centre of education for society to overcome various problems, including the issues of terrorism and radical movements in Indonesia. The efforts of pesantren to prepare their santri with keen understanding and spirituality in Islam are in harmony with Indonesia's aims to be a peaceful country. It depicts that the existence of pesantren within Indonesian society gives social impact to make people being safe in their life.

Furthermore, the existence of pesantren and santri can be said as the agents of peace. It is crucial for the government to give more attention to the development of pesantren as a non-profit institution since they help the government to obtain the national interests of the country. They support the government to provide more qualified education institution

\footnotetext{
${ }^{33}$ Nurrohman Syarif, "Pesantren Sebagai Penangkal Radikalisme dan Terorisme," 2010, (Research, Universitas Islam Negeri (UIN) Sunan Gunung Djati, 2010), p. 119.

${ }^{34}$ Ferry Muhammadsyah Siregar, "Religious Leader and Charismatic Leadership in Indonesia: The Role of Kyai in Pesantren in Java," in Jurnal Kawistara, Vol. 3, No. 2, 2013, p. 140.
} 
for children as well as being as the catalyst protecting people from extreme understanding and movement of Islam.

\section{The Roles of Pesantren in Facing Terrorism Issues}

Having some modalities as mentioned above, the pesantren in Malang has already played prominent roles both internally and externally, to face the issues of terrorism. The explanation can be seen as follows.

\section{Internal Roles of Pesantren}

Based on the various modalities mentioned above and the results of data collections from various pesantren in Malang with their different backgrounds in the movement, it was found that none of the pesantren supported the teaching of terrorism. They explained that they had made significant efforts and participation to combat the fundamental understanding, which is developed within the society.

There are some internal efforts of pesantren in facing the issues of terrorism in the area of Malang; Firstly, increasing religious spirit of Islamic teaching in the pesantren education system. Since the religious spirit teaches people on how to be the right person implemented in their social life, pesantren seriously concerns on various activities to keep the religious spirit of the santri. Some programs which have become the daily and duty agendas of the santri are reciting Qur'an along with understanding the meaning, performing tahajjud prayer, doing five times prayers in the mosque, fasting, and following the preaching activities with kyai. Through some of these activities which are mostly connected to religious activities, directly or indirectly, pesantren have built strong characteristics of santri to be good persons. For students who do not follow these activities, the pesantren team have a system to give punishment to the santri.

Second, the internalisation of Islamic values in the curriculum through thematic learning subjects. In terms of curriculum, learning is based on the study of the books of previous scholars to understand Qur'an and hadiths. Therefore, the curriculum of pesantren teaches students to be able to perform Islam as a blessing religion for the universe. In some meetings, the kyai teaches students to support peace and security in life-based on Islamic values.

In pesantren, the santri study how to give benefits to as many people as possible since Prophet Muhammad said that the best among you are those who give more roles and contribution to society. The santri actively prepare themselves to be the ideal persons, and the pesantren create the system for that purpose. Moreover, the students study the attitudes and morals in interacting with everybody, not only Muslims but also non-Muslims, before getting more knowledge about Islam. In the curriculum taught in the pesantren of Malang, it is clear that tolerance value is one of the primary and prominent topics given to the santri. 
By such roles played by pesantren, santri and alumni can play their strategic and ideal position within the society with different kinds of their profession. Most of the santri and alumni of pesantren understand how to bring the values of honesty, tolerance, moderate, inclusive and respect the plurality in their life since all of those principles are the messages of Islam. ${ }^{35}$

The last, the pesantren have already strengthened the close relations between kyai and santri to help convey the messages of Islam. Some of the strategies are by performing routine Islamic preaching by kyai and opening regular session for santri to consult their problems with kyai. Moreover, the meeting and interaction of kyai with santri after five times prayers also make santri become closer and have no barrier to communicate with kyai. Usually, kyai will also summon for and ask about the news of santri condition informally.

For the pesantren in Malang, these efforts are essential to prepare the generations who can prevent and face the threat of terrorism. In the various occasion, kyai convey the messages of Islam to the santri to fully following the Islamic lifestyle. Either in his preaching or informal communication, kyai ask the santri to spread and show the spirit of peace during their interaction with their friends, family and society.

However, the model of the relationship between kyai and santri is not only close but also is coloured by the authority. A kyai becomes a role model for santri to prepare their future profile. Therefore, they become very close and santri learn a lot from kyai about how to position themselves within society. With this model, kyai has prepared the santri to face the issues of terrorism.

\section{External Roles of Pesantren}

The external effort that has been made by pesantren is by conducting intensive and routine dialogues and cooperations with many parties, including government agencies, in facing the issues of terrorism in the area of Malang. Three central institutions which have established collaboration with the pesantren are local government, police, and military. In some events, they often collaborated with government, at least to build mutual understanding among them in finding the solution for terrorism issues.

The pesantren and government institutions in Malang maintain a good relationship. The local government, the police and the military have been actively involved in the Islamic learning held by religious leaders in the area of Malang. On the other hand, the local government, the police and the military also often invited national or local Islamic scholar and clerics to give Islamic preaching for their officers. Such close relations gave many advantages for both government agencies and pesantren. They can communicate and share information

${ }^{35}$ Suprapto, "Deradikalisasi Agama Melalui Pendidikan Multikultural-Inklusiv (Studi Pada Pesantren Imam Syuhodo Sukoharjo)," in Profetika: Jurnal Studi Islam Vol. 15, No. 02, 2016, p. $246-260$. 
well with each other without suspicion. For example, one of the pesantren leaders often provided information to the police about the individuals who have the potential for being terrorist since he/she has a fundamental understanding of Islam.

Moreover, the pesantren actively support the government to face the issues of terrorism. One of the prominent activities they perform is strengthening religious values within the society with a moderate understanding of Islam. It could be done since the kyai in pesantren, and the best santri will have their external duty to convey the message of dakwah to the society, besides their preaching in pesantren.

Moreover, pesantren in Malang has already conducted some programs for solving social and economic problems of the people, for example, by doing some social works. They opened donation from the people and distributed to some areas it needs. However, some of these programs were not well-managed since the form of the programs mostly were incidental and had not actively collaborated with the government. In the perspective of terrorism roots, if the collaboration of pesantren and government can help to find the solution of social and economic problems, the potential of terrorism in a particular area can be minimised.

The last external effort was establishing a good relationship with the former terrorists. The support of former terrorists is significant since they can give a deep understanding of the terrorist movement's links in Indonesia. Based on in-depth interviews with police, it is found that the former prisoner terrorist, M. Kholili, often became a vital informant related to the terrorist movement in Indonesia. Information from Kholili can be developed into an advanced investigation or direct mapping of the terrorist movement in Malang.

The existence of pesantren to do approach with the former terrorists is principle because the ideological and religious perspective can be used. Psychologically, the former terrorists feel more convenience telling their stories with those who understand the logic of their mistakes. In this case, some of the prominent persons from pesantren in Malang have already collaborated with the government to maintain a close relationship with the former terrorists. In order to collect the information of religious logic, the government needs help from prominent persons in pesantren.

\section{Conclusion}

Based on the results of research on the roles of pesantren in facing the issues of terrorism in Malang, it is found that there are some modalities owned by as well as roles which have been played by pesantren to face the issues of terrorism in Indonesia. At least, by its existence as the educational institutions, the pesantren have four modalities to face the issues of terrorism. First, increasing the religious spirit of Islamic teaching in the pesantren's education system. Second, the internalisation of Islamic values in the pesantren education curriculum through thematic learning subjects. Third, the closeness of relations between the kyai and santri, 
which makes the delivery of Islamic teachings easier. Finally, the encouragement roles of pesantren within the society by promoting the excellent image and Islamic messages through kyai, santri, and alumni.

These four modalities have been used optimally as the commitment of pesantren to face the influence of radical movements within the society. Both internal and external efforts have been made by pesantren in the area of Malang to face the issues of terrorism. Moreover, in conducting their roles, pesantren gain support from the local government of Malang, police and the military. In many occasions, they share information and discuss the best way to face the issues of terrorism development in their area. Furthermore, by the facilitation of the government, the pesantren have access to communicate with the former terrorist prisoners who are willing to protect the santri and society not to be easily trapped in a global terrorist network.

\section{Acknowledgement}

The material of this paper is based on the research funded by the Indonesian Ministry of Higher Education, Research and Technology under the Grant of Penelitian Dasar Unggulan Perguruan Tinggi (PDUPT), and supported by University of Muhammadiyah Malang.

\section{References}

Ainun, Yatimul. "Majalah ISIS Beredar di Malang," in https://regional. kompas.com, Agustus 2014.

Andari, Ken, Dadang Rahmat Hidayat, dan Efi Fadilah. "Konstruksi Majalah Gatra Tentang Radikalisme di Pesantren," in Students E-Journal Vol. 1, No. 12012.

Bjørgo, Tore. Root Causes of Terrorism: Myths, Reality and Ways Forward. London: Routledge, 2004.

Bramantyo. "12 Daerah di Indonesia Masuk Zona Merah Terorisme, Termasuk Jawa Tengah," in https://news.okezone.com/, September 11, 2018.

Della Porta, Donatella, and Gary LaFree. "Guest Editorial: Processes of Radicalization and de-Radicalization," in International Journal of Conflict and Violence (IJCV) Vol. 6, No. 12012.

Dyson, Jane. "The Meaning of Spirituality: A Literature Review," in Journal of Advanced Nursing, 1997, 6.

Feith, Douglas J. War and Decision: Inside the Pentagon at the Dawn of the War on Terrorism. New York: Harper Collins Publishers, 2008.

Hijriah, Hanifiyah Yuliatul. "Spiritualitas Islam dalam Kewirausahaan," in Tsaqafah Vol. 12, No. 12016.

Ibrahim, Rustam. "Pesantren dan Pendidikan Kebangsaan: Studi Tentang Buku Al-difâ" 
'Ani Al-wathân Min Ahammi Al-Wâjibât 'Ala Kulli Wâhidin Minnâ Karya Kiai Muhammad Said," in MIQOT: Jurnal Ilmu-ilmu Keislaman, Vol. 42, No. 12018.

Ja'far, Ja'far. "Respons Al Jam'iyatul Washliyah Terhadap Terorisme," in Akademika: Jurnal Pemikiran Islam, Vol. 22, No. 1, 2017.

Khairur Rijal, Najamuddin. "Local Governance Dalam Merespons Isu dan Ancaman ISIS: Kasus di Kota Malang," in Jurnal Social Politik Vol. 2, no. 1, 2017: 85-102.

Lewis, James Andrew. Assessing the Risks of Cyber Terrorism, Cyber War and Other Cyber Threats. Washington DC: Center for Strategic \& International Studies, 2002.

Lizardo, Omar A., and Albert J. Bergesen. "Types of Terrorism by World System Location," in Humboldt Journal of Social Relations, 2003, 162-192.

Mu'allim, Amir. "Isu Terorisme dan Stigmatisasi Terhadap Pondok Pesantren (Meluruskan Kesalahpahaman terhadap Pondok Pesantren," in Millah: Jurnal Studi Agama Vol. 6, No. 1 (2006): 47-60.

Mukhibat, Mukhibat. "Deradikalisasi dan Integrasi Nilai-Nilai Pluralitas dalam Kurikulum Pesantren Salafi Haraki di Indonesia," in Al-Tahrir: Journal of Islamic Thought, Vol. 14, No. 1, 2014.

Muslihah, Eneng. "Pesantren dan Pengembangan Pendidikan Perdamaian Studi Kasus di Pesantren An-Nidzomiyyah Labuan Pandeglang Banten," in Analisis: Jurnal Studi Keislaman Vol. 14, No. 2 (2014): 311-40.

Nilan, Pam. "The 'Spirit of Education' in Indonesian Pesantren," in British Journal of Sociology of Education Vol. 30, No. 2, 2009: 219-232.

Parsons, Jemma. Peran Pesantren dan Cita-Cita Santri Putri: Sebuah Pembandingan Diantara Dua Pondok Pesantren di Jawa. Malang: Universitas Muhammadiyah Malang, 2004.

Rose, Gregory, and Diana Nestorovska. "Towards an ASEAN Counter-Terrorism Treaty." SYBIL 9, 2005: 157.

Satha-Anand, Chaiwat. "The Nonviolent Crescent," dalam Non killing Spiritual Traditions. Nonkilling Studies. Center for Global Nonkilling, 2015.

Sayyidati, Adibah. “Jawa Pos's News Reporting About Islamic State of Iraq and Syria (ISIS) in East Java on Peace Journalism Perspective: Potret Jawa Pos Tentang Islamic State of Iraq and Syria (ISIS) di Jawa Timur Dalam Perspektif Jurnalisme Perdamaian," in Jurnal Pekommas Vol. 3, No. 1 (April 2018).

Siregar, Ferry Muhammadsyah. "Religious Leader and Charismatic Leadership in Indonesia: The Role of Kyai in Pesantren in Java," in Jurnal Kawistara Vol. 3, No. 2 2013.

Smith, Anthony L. "The Politics of Negotiating the Terrorist Problem in Indonesia," in Studies in Conflict \& Terrorism, Vol. 28, No. 1 2005: 33-44.

Suprapto, Rohmat. "Deradikalisasi Agama Melalui Pendidikan Multikultural-Inklusiv: Studi Pada Pesantren Imam Syuhodo Sukoharjo," in Profetika: Jurnal Studi Islam Vol. 15, No. 02, 2016: 246-260. 
Syafirdi, Didi. "5 Masjid Disinyalir Jadi Tempat Penyebaran Paham ISIS di Malang," in https://www.merdeka.com, Agustus 2014.

Syarif, Nurrohman. "Pesantren Sebagai Penangkal Radikalisme dan Terorisme," 2010.

Syahnan, Mhd. Contemporay Islamic Legal Discourse: A Study of Sayyid Quthb's Fi Zhilal al-Qur'an. Medan: IAIN Press, 2010.

Syahnan, Mhd. "Islam as a System: A Critical Analysis of Sayyid Quthb's Principle Thought," in Analitica Islamica, Vol. 4, No. 1, 2002, p. 45-57.

Tuathail, Gearoid. "Just out Looking for a Fight': American Affect and the Invasion of Iraq," in Antipode Vol. 35, No. 5 (2003): 856-870.

Vaughan, Frances. "What Is Spiritual Intelligence?," in Journal of Humanistic Psychology Vol. 42, No. 2 (April 2002): 16-33.

Yumitro, Gonda. "Kebijakan Pemerintah Indonesia Dalam Global War Against Terrorism," dalam Prosiding Vennas 7 AIHII Di Universitas Hasanuddin, Makassar, Dengan Tema Benua Maritim Indonesia Dalam Perspektif Hubungan Internasional, November 23, 2016.

Yumitro, Gonda. "Terrorism, Islam and International Politics," in Jurnal Studi Hubungan Internasional, Vol. 2, No. 22012.

Zakaria, Gamal Abdul Nasir. "Pondok Pesantren: Changes and It's Future," in Journal of Islamic and Arabic Education, Vol. 2, No. 2 2010: 45-52.

Zamroni, Imam. "Islam, Pesantren dan Terorisme," in Jurnal Pendidikan Agama Islam Vol. 2, No. 22005. 